\title{
$\mathrm{Cu} / \mathrm{Ni} /$ Polyimide 시스템의 접착력 및 계면화학반응
}

\author{
최철민 · 채홍철·김명한 \\ 충북대학교 공과대학 신소재공학과

\section{The Adhesion Strength and Interface Chemical Reaction of $\mathrm{Cu} / \mathrm{Ni} / \mathrm{Polyimide}$ System}

\author{
Chul Min Choi, Hong Chul Chae and Myung Han Kim \\ Department of Materials Engineering, Chungbuk National University, 12 Gaesin-dong, Cheongju 361-763, korea
}

(2007년 11월 11일 접수 : 2007년 12월 10일 채택)

\begin{abstract}
The magnetron sputtering was used to deposit Ni buffer layers on the polyimide surfaces to increase the adhesion strength between $\mathrm{Cu}$ thin films and polyimide as well as to prevent $\mathrm{Cu}$ diffusion into the polyimide. The Ni layer thickness was varied from 100 to $400 \AA$. The adhesion strength increased rather significantly up to $200 \AA$ of $\mathrm{Ni}$ thickness, however, there was no significant increase in strength over $200 \AA$. The XPS analysis revealed that $\mathrm{Ni}$ thin films could increase the adhesion strength by reacting with the polar $\mathrm{C}=\mathrm{O}$ bonds on the polyimide surface and also it could prevent $\mathrm{Cu}$ diffusion into the polyimide. The $\mathrm{Cu} / \mathrm{Ni} /$ polyimide multilayer thin films showed a high stability even at the high heating temperature of $200^{\circ} \mathrm{C}$, however, at the temperature of $300^{\circ} \mathrm{C}$, Cu diffused through the Ni buffer layer into polyimide, resulting in the drastic decrease in adhesion strength.
\end{abstract}

Key words $\mathrm{Ni}$ buffer layer, Polyimide, Adhesion, $\mathrm{Cu}$ diffusion.

\section{1. 서 론}

폴리이미드(Polyimide)는 dianhydride(R)와 diamine이 이미드 $[(\mathrm{RCO}) 2 \mathrm{NR}]$ 결합하여 main chain을 형성하는 유 기 고분자의 한 종류로서 우수한 열적, 화학적 안정성, 낮은 유전상수 및 우수한 성형성등을 보유하고 있어 새 로운 층간 절연막으로서 컴퓨터 회로기판이나, 혼성 기 판, $\mathrm{TAB}$ (Tape Audio Bonding), $\mathrm{FPCB}$ (Flexible Printed Circuit Board)등에 널리 적용되고 있다.,2) 이러한 폴리 이미드는 배선재로서 구리박막을 코팅하여 사용하는데 이 때 극성기가 없는 폴리이미드와 구리 배선사이에 접착력 이 낮아 박리의 가능성이 있고 또한 폴리이미드에 대한 구리금속의 확산속도가 비교적 커서 장기간 사용시 폴리 이미드의 절연특성을 훼손시킬 위험성이 있다.")

폴리이미드와 $\mathrm{Cu}$ 박막사이에 buffer layer금속박막의 설 치는 상기의 문제점을 해결할 수 있는 방안으로 제시되 었고, 관련된 연구가 진행되어 왔다. ${ }^{4,5)}$ 기존연구에서는 buffer layer 층으로 $\mathrm{Cr}$ 을 가장 많이 사용하였는데 $\mathrm{Cr}$ 을 사용할 경우 접착력은 증가시킬 수 있으나 $\mathrm{Cr}$ 박막의 높 은 잔류응력으로 인하여 표면에 grain-like creak이 발생

${ }^{\dagger}$ Corresponding author

E-Mail : myunghan@cbnu.ac.kr (M. H. Kim)
하게 된다. 이러한 creak은 $\mathrm{Cu}$ 가 제기능을 못하게 하며 또한 수분의 중요한 침투경로가 되어 polyimide와 $\mathrm{Cu}$ 사 이의 접착력을 낮추기 때문에 제품의 신뢰성을 저하시키 는 주된 요인이 된다.

본 연구에서는 이러한 $\mathrm{Cr}$ buffer layer의 문제점을 극 복하고자 $\mathrm{Ni}$ 을 buffer layer박막으로 사용하여 접착력향 상과 폴리이미드에 대한 $\mathrm{Cu}$ 확산을 방지하고자 하였으며, 이 러한 $\mathrm{Cu} / \mathrm{Ni} /$ polymide 다층박막 구조에서 $\mathrm{Ni}$ 박막의 두께 에 따른 접착력 및 $\mathrm{Ni} /$ polyimide 계면에서의 계면화학상 태의 변화를 조사하여 최적의 $\mathrm{Cu} / \mathrm{Ni} /$ polymide 다층박막 구조를 얻고자 하였다. 또한 열처리온도에 따른 폴리이 미드의 표면상태 및 다층박막구조에서의 $\mathrm{Ni} /$ polyimide 계 면의 계면화학상태의 변화를 조사함으로서 $\mathrm{Cu} / \mathrm{Ni} / \mathrm{polymide}$ 다층박막구조의 열적안정성을 연구하고자 하였다.

\section{2. 실험 방법}

기판으로는 필름 형태로 완전히 curing된 $50 \mu \mathrm{m}$ 두께 의 Pyromellitic Dianhydride Oxydianiline(PMDA-ODA) $10 \times 50 \mathrm{~mm}$ 폴리이미드 (DuPont의 Kapton E) 기판을 사 용하였고, 기판 표면의 불순물 및 수분제거를 위해 에틸 알코올에 넣어서 초음파 세척기로 30 분간 세척 후 진공 상태 $\left(10^{-6}\right.$ torr $)$ 에서 $50^{\circ} \mathrm{C}$ 에서 30 분동안 유지시켜 주었다. 
이 기판위에 $\mathrm{Ni}$ 및 $\mathrm{Cu}$ 박막을 $\mathrm{DC}$ Magnetron Sputtering System을 이용하여 순차적으로 증착시켰으며, 타겟은 $5.08 \mathrm{~cm}$ 직경의 $\mathrm{Ni}(3 \mathrm{~N})$ 및 $\mathrm{Cu}(5 \mathrm{~N})$ 타겟을 사용하였다.

$\mathrm{Ni}$ 의 증착은 $90 \mathrm{~W}$ DC power에서 $1.2 \AA / \mathrm{sec}$ 증착속도 로 하였으며, $\mathrm{Ni}$ 박막층의 두께는 $100 \AA \sim 400 \AA$ 이었다. $\mathrm{Ni}$ 증착 후 연속적으로 $\mathrm{Cu}$ 박막을 증착하였으며 $120 \mathrm{~W} \mathrm{DC}$ power 및 $5 \AA / \mathrm{sec}$ 의 증착속도에서 증착시켰고, 목표 $\mathrm{Cu}$ 의 증착두께는 $\mathrm{Ni}$ 층과 합하여 최종두께가 $3000 \AA$ 가 되 도록 하였다.

접착력 측정은 $90^{\circ}$ peel test 방법을 이용하여 측정하 였다. 이때 사용한 로드셀의 용량은 $5 \mathrm{Kgf}$ 이었으며 2 $\mathrm{mm} / \mathrm{min}$ 의 인장속도로 잡아당겨서 peel curve를 구하였 다. Peel curve에서 균일한 하중이 나올 때의 값을 읽은 후 시편의 너비로 이 값을 나누어 필 접착강도를 측정 하였고, 10 회 측정값의 평균값을 취하였다.

$\mathrm{Ni} / \mathrm{Cu}$ 박막층과 polyimide의 계면화학반응을 알아보기 위 해서, peel test후 박리된 폴리이미드 계면(peeled polyimide interface)에 대해 XPS(VG사의 ESCALAB 210 system) 분석을 행하였고, 이때 XPS를 위한 X-ray source 로는 $\mathrm{Mg} \mathrm{K} \alpha(1253.6 \mathrm{eV})$ 를 사용하였다. XPS deconvolution 프 로그램으로는 XPSPEAK41을 이용하였다.

온도의 변화가 폴리이미드와 박막사이의 접착강도 및 화학적 결합에 어떻게 영향을 주는 가를 조사하기 위하 여 열처리온도의 변화에 따른 이런 특성의 변화를 측정 분석하였다. 열처리는 전기로를 이용하여 대기중에서 $100^{\circ} \mathrm{C}$ $350^{\circ} \mathrm{C}$ 온도 범위에서 실시하였고, 열처리후 다층박막의 접착력 및 계면화학상태는 $90^{\circ}$ peel test 방법 및 XPS를 이용하여 분석하였다.

\section{3. 결과 및 고찰}

\subsection{Ni/Polyimide 계면의 화학적상태 및 접착력}

Fig. 1은 폴리이미드 기판위에 $\mathrm{Ni}$ 박막의 두께를 $100 \AA$ 에서 $400 \AA$ 까지 변화를 주어 제조한 $\mathrm{Cu} / \mathrm{Ni} /$ polyimide 다 층박막 시편을 peel test하여 얻은 폴리이미드 계면에 대 한 wide-scan XPS spectra이다. 여기에서 결합에너지 $287 \mathrm{eV}$ 부근에서 $\mathrm{C} 1 \mathrm{~s}$ 피크, $403 \mathrm{eV}$ 부근에서 $\mathrm{N} 1 \mathrm{~s}$ 피크 그 리고 $533 \mathrm{eV}$ 부근에서 $\mathrm{O} 1 \mathrm{~s}$ 피크가 나타난 것을 알 수 있

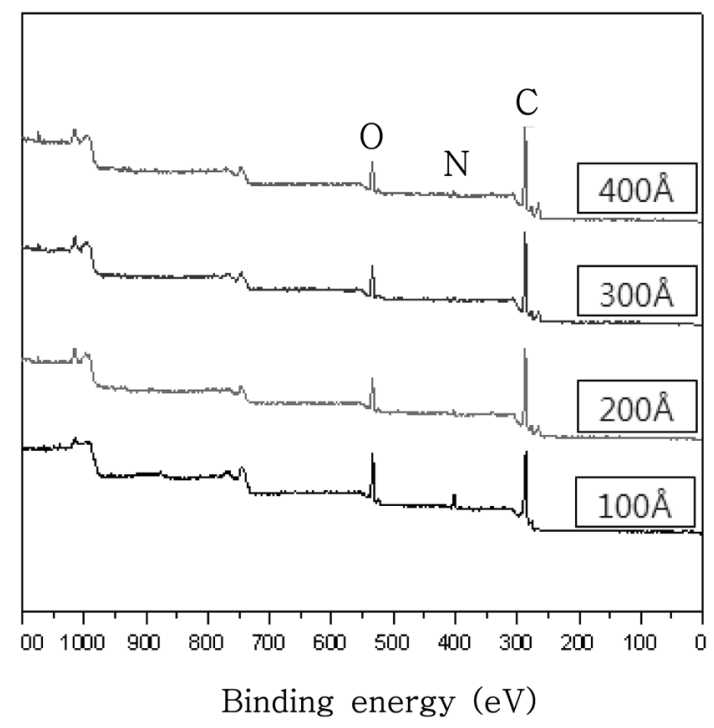

Fig. 1. The wide scan XPS-spectra on the peeled polyimide surface as a function of $\mathrm{Ni}$ thickness.

다. 그러나 폴리이미드 표면에서 $\mathrm{Ni}$ 이 나타나지 않은 것 으로 보아 폴리이미드에 잘 확산하여 들어가는 $\mathrm{Cu}$ 에 비 해 $\mathrm{Ni}$ 은 폴리이미드에 확산되어 침투하지 않는 것을 알 수 있었고, Ni층이 buffer layer 역할을 충분이 해냈음을 보여준다. Table 1은 Fig. 1의 wide-scan XPS spectra에 나타난 $\mathrm{C}, \mathrm{N}$ 및 $\mathrm{O}$ 원소의 상대적 조성비를 XPS에 의 해 정량 분석한 결과로, Ni buffer layer의 두께가 $200 \AA$ 까지는 $\mathrm{O} 1 \mathrm{~s}$ 가 감소하고 $\mathrm{C} 1 \mathrm{~s}$ 는 증가하나, $200 \AA$ 이상에서 는 $\mathrm{O} 1 \mathrm{~s}$ 와 $\mathrm{C} 1 \mathrm{~s}$ 의 상대적조성비의 변화는 미미한 것을 알 수 있다. O1s가 감소되는 것은 peel test시 폴리이미드 표면에 결합본드 $(\mathrm{C}=\mathrm{O})$ 로서 존재하는 산소와 결합된 $\mathrm{Ni}$ 이 산소와 함께 폴리이미드로 부터 분리되기 때문인 것 으로 판단된다. ${ }^{6}$ Fig. 2는 Ni박막 두께에 따른 폴리이미 드 계면에서 C1s core-level XPS spectra이다. 여기서 $\mathrm{Cls}$ 의 spectra는 charge effect 때문에 약 $4 \mathrm{eV}$ 낮은 에너지 쪽으로 변환되었고, 284.6, 285.6, 286.4, 287.5 및 $288.5 \mathrm{eV}$ 에서 나타나는 피이크는 각각 C-C, C-O-C 또는 C-N, $\mathrm{C}-\mathrm{O}$, amide 및 $\mathrm{C}=\mathrm{O}$ 결합본드에 해당된다. ${ }^{7)}$ Table 2 는 Fig. 2에 나타난 각 결합본드 피이크에 대한 deconvolution 결과로 각 화학결합 구성요소의 상대적 조성비를 보여 주

Table 1. The elemental ratios on the peeled polyimide surfaces as a function of Ni thickness, obtained from the wide scan XPSspectra.

\begin{tabular}{ccccc}
\hline \hline \multirow{2}{*}{ Sample } & & \multicolumn{3}{c}{ Elemental ratio (at.\%) } \\
\cline { 3 - 5 } & & O1s & N1s & C1s \\
\hline \multirow{2}{*}{$\mathrm{Ni}$} & $100 \AA$ & $20.53 \%$ & $6.86 \%$ & $82.61 \%$ \\
Thickness & $200 \AA$ & $16.26 \%$ & $3.57 \%$ & $80.16 \%$ \\
& $300 \AA$ & $16.86 \%$ & $3.03 \%$ & $80.17 \%$ \\
\hline
\end{tabular}


Table 2. The binding component ratios on the peeled polyimide surface as a function of Ni thickness, obtained from the C1s XPS spectra.

\begin{tabular}{cccccc}
\hline \hline \multirow{2}{*}{ Sample } & & \multicolumn{4}{c}{ Binding component ratio (\%) } \\
\cline { 3 - 6 } & & $\begin{array}{c}\mathrm{C}=\mathrm{O} \\
(288.3 \mathrm{eV})\end{array}$ & $\begin{array}{c}\mathrm{C}-\mathrm{O} \\
(286.4 \mathrm{eV})\end{array}$ & $\begin{array}{c}\mathrm{C}-\mathrm{O}-\mathrm{C} \\
(285.6 \mathrm{eV})\end{array}$ & $\begin{array}{c}\mathrm{C}-\mathrm{C} \\
(284.6 \mathrm{eV})\end{array}$ \\
\hline \multirow{3}{*}{$\mathrm{Ni}$} & $100 \AA$ & $12.30 \%$ & $22.07 \%$ & $31.46 \%$ & $34.17 \%$ \\
Thickness & $200 \AA$ & $8.56 \%$ & $26.37 \%$ & $32.42 \%$ & $32.99 \%$ \\
& $300 \AA$ & $7.63 \%$ & $26.37 \%$ & $30.77 \%$ & $35.23 \%$ \\
& $400 \AA$ & $7.40 \%$ & $26.08 \%$ & $31.53 \%$ & $34.99 \%$ \\
\hline
\end{tabular}

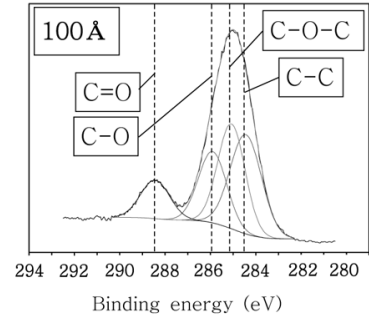

(a)

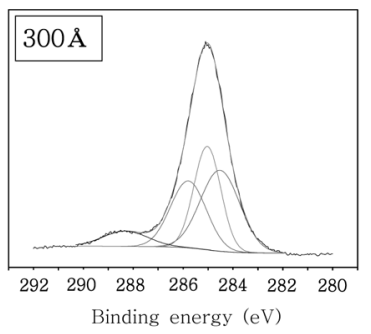

(c)

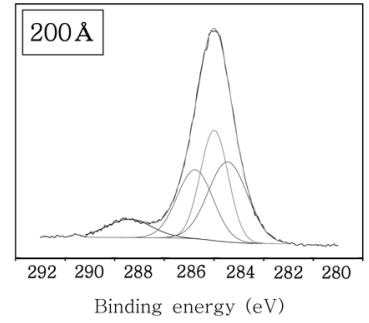

(b)

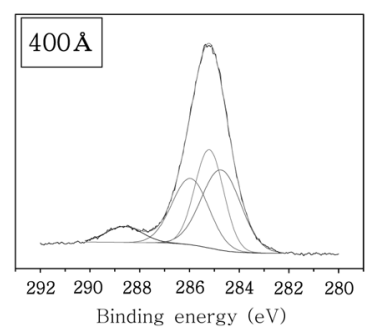

(d)
Fig. 2. The C1s-XPS spectra on the peeled polyimide surface as a function of Ni thickness: (a) $100 \AA$, (b) $200 \AA$, (c) $300 \AA$, (d) $400 \AA$

고 있다. 여기서, $\mathrm{Ni}$ 박막의 두께가 $200 \AA$ 까지 증가 할 수록 $\mathrm{C}=\mathrm{O}$ 본드는 비교적 큰 폭으로 감소하고, 상대적 으로 $\mathrm{C}-\mathrm{O}$ 본드는 큰 폭으로 증가하나 그 이상의 두께에 서는 변화의 정도가 매우 미미하다. 이는 $\mathrm{Ni}$ 박막과 폴 리이미드 표면의 $\mathrm{C}=\mathrm{O}$ 본드가 반응함에 따라 $\mathrm{C}=\mathrm{O}$ 본드 가 분해되고 $\mathrm{C}-\mathrm{O}$ 본드가 생성되는데 기인 ${ }^{6)}$ 하는 것이며, 이 러한 반응은 주로 $\mathrm{Ni} /$ 폴리이미드 계면에서 발생되어 $\mathrm{Ni}$ 박막의 두께가 어느 이상 $(200 \AA)$ 이 되면 큰 변화를 보이 지 않게 되는 것이다. 또한, $\mathrm{C}-\mathrm{O}-\mathrm{C}$ 나 $\mathrm{C}-\mathrm{C}$ 는 큰 변화를 보이지 않는 것으로 보아 이들 본드가 $\mathrm{Ni}$ 박막층과의 반 응에 관여하지 않음을 보여주고 있다.

Fig. 3은 $\mathrm{Cu} / \mathrm{Ni} /$ polyimide다층박막에서 $\mathrm{Ni}$ 박막 두께에 따른 peel strength의 변화를 보여주고 있다. 여기서 peel strengh 값은 $\mathrm{Ni}$ 박막층의 두께가 증가하면서 $200 \AA$ 까 지는 큰 폭으로 증가하다가 $200 \AA$ 이후 부터는 매우 완 만하게 증가하고 있는데 이러한 결과는 Table 2의 $\mathrm{C}=\mathrm{O}$ 및 $\mathrm{C}-\mathrm{O}$ 본드의 상대적 조성비의 변화와 일치하고 있다.

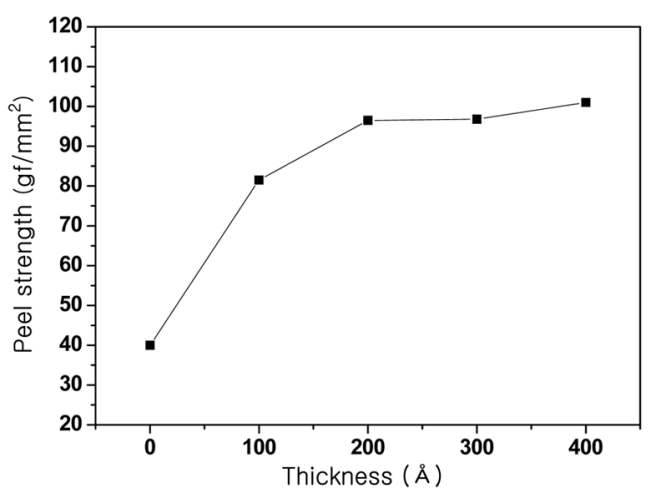

Fig. 3. The change of peel strength as a function of $\mathrm{Ni}$ thickness.

이러한 결과는 $\mathrm{Cu}$ 와 폴리이미드박막 사이에 buffer layer 로서 사용된 $\mathrm{Ni}$ 이 폴리이미드의 $\mathrm{C}=\mathrm{O}$ 본드와 반응하여 계면접착력 향상에 기여함을 입증하고 있다. 또한 $\mathrm{Cu}$ 에 비해 $\mathrm{Ni}$ 이 폴리이미드와 더 강력한 접착력을 갖고 있음 을 보여주고 있으며, 접착력향상을 위한 최소 Ni buffer layer층의 두께는 $200 \AA$ 이다.

\section{2. 열처리온도에 따른 $\mathrm{Cu} / \mathrm{Ni} /$ Polyimide 다층박막 의 계면화학상태 및 접착력}

Fig. 4는 열처리온도에 따른 PI의 계면에서의 wide-

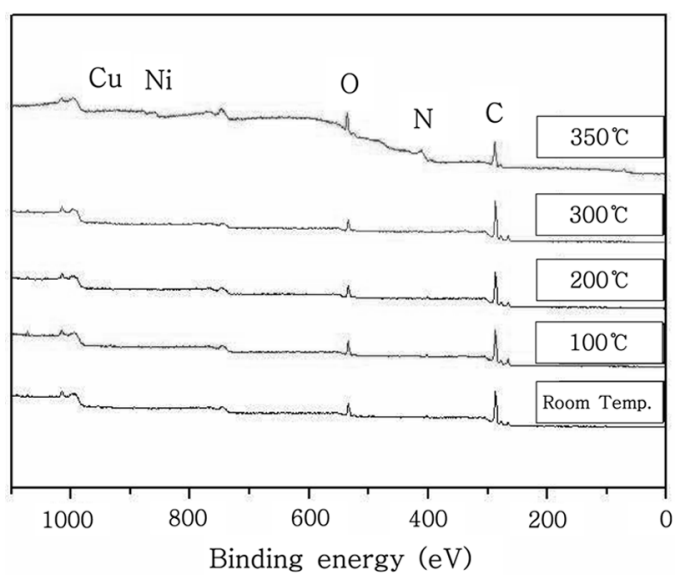

Fig. 4. The wide scan XPS-spectra on the peeled polyimide surface as a function of heat treatment temperature. 
scan XPS spectra로, $300^{\circ} \mathrm{C}$ 의 열처리온도까지는 피이크 의 큰 변화를 볼 수 없으나, 열처리온도가 $350^{\circ} \mathrm{C}$ 에서는 $853 \mathrm{eV}$ 에서 Ni2p 피이크가 나타나고 있다. $\mathrm{Cu} 2 \mathrm{p}$ 피이크 는 $933 \mathrm{eV}$ 에서 관찰되어야 하나 조성이 크지 않아 피이 크를 확인할 수 없었다. Table 3은 이 spectra에 나타난 $\mathrm{O}, \mathrm{N}, \mathrm{C}, \mathrm{Cu}$ 및 $\mathrm{Ni}$ 원소의 상대적 조성비를 XPS로 분 석하여 얻은 결과이다. 여기에서 열처리온도가 $200^{\circ} \mathrm{C}$ 까 지는 단지 폴리이미드의 구성요소인 $\mathrm{O}, \mathrm{N}$ 및 $\mathrm{C}$ 이 검출 이 되고 있으나 열처리 온도가 $300^{\circ} \mathrm{C}$ 로 상승하면 경우 coating layer박막인 $\mathrm{Cu}$ 가 나타나기 시작하는 것을 알 수 있다. 이러한 결과는 폴리이미드에 확산이 잘되는 $\mathrm{Cu}$ 가 $300^{\circ} \mathrm{C}$ 이상의 높은 열처리온도에서 $\mathrm{Ni}$ 층을 확산하여 통과 한 후 다시 폴리이미드로 확산하여 들어간 것으로 사료 된다. ${ }^{3)}$ 이러한 폴리이미드내에 $\mathrm{Cu}$ 의 확산은 폴리이미드 의 절연체 기능을 저해시키고 접착력도 하락시키는 것으 로 알려져있고, ${ }^{3)}$ 본 연구에서 측정된 peel strength의 결 과도 이를 뒷받침 하고 있다. 한편 $350^{\circ} \mathrm{C}$ 의 열처리 온 도에서는 $\mathrm{Cu}$ 와 아울러 $\mathrm{Ni}$ 의 존재도 확인되고 있는데 이 는 $350^{\circ} \mathrm{C}$ 의 고온에서 $\mathrm{Cu} / \mathrm{Ni} /$ polyimide다층박막은 육안으 로 보아 이미 심하게 변형된 상태이고 이 와중에 $\mathrm{Ni}$ 이 기계적인 압력을 받아 폴리이미드 표면에 부착되었을 가 능성과 $\mathrm{Cu}$ 와 같이 $\mathrm{Ni}$ 도 고온에서는 폴리이미드에 확산 되어 존재할 가능성을 제시할 수 있다.

Fig. 5는 열처리온도에 따른 폴리이미드 계면에 대한 $\mathrm{C} 1 \mathrm{~s}$ core-level XPS spectra이다. C1s의 spectra는 charge effect 때문에 약 $4 \mathrm{eV}$ 낮은 에너지 쪽으로 이동되었고, 여기서 284.6, 285.6, 286.4, 287.5 및 $288.5 \mathrm{eV}$ 에서 나 타나는 피이크는 각각 C-C, C-O-C 또는 C-N, C-O, amide 및 $\mathrm{C}=\mathrm{O}$ 의 본드에 해당된다. Table 4 는 Fig. 5 의 $\mathrm{C} 1 \mathrm{~s}$ 의 spectra 보이는 여러 본드의 상대적 조성비를 구 하기 위해 정밀 휘팅하여 얻은 결과이다. 여기에서 열처 리 온도가 $100^{\circ} \mathrm{C}$ 와 $200^{\circ} \mathrm{C}$ 일 때, $\mathrm{C}=\mathrm{O}$ 와 $\mathrm{C}-\mathrm{O}$ 본드를 비롯한 각 결합본드의 상대적 조성비는 큰 변화가 없었 으나, $300^{\circ} \mathrm{C}$ 의 열처리 온도에서는 $\mathrm{C}=\mathrm{O}$ 본드가 감소하고 $\mathrm{C}-\mathrm{O}$ 본드가 증가하였다. 이러한 결과는 상기에서 이미 언 급된 폴리이미드에로의 $\mathrm{Cu}$ 의 확산에 기인된다 사료된다.

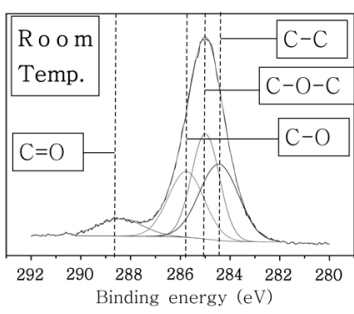

(a)

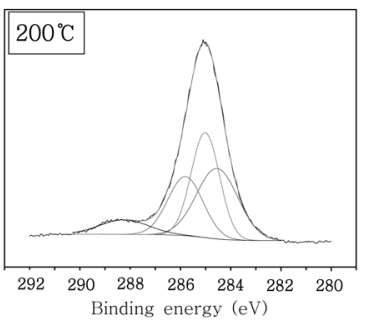

(c)

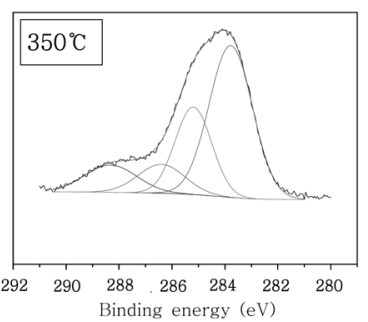

(e)

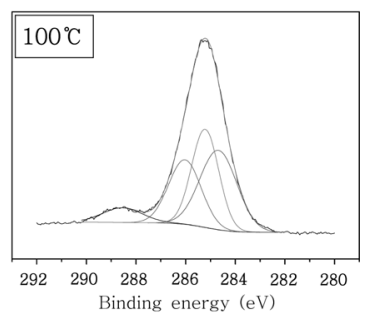

(b)

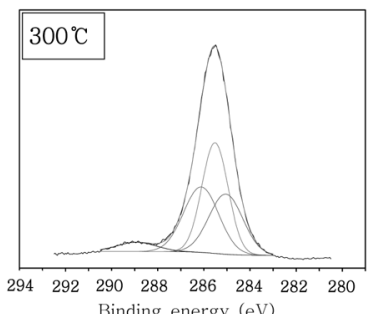

(d)
Fig. 5. The C1s-XPS spectra on the peeled polyimide surface as a function of heat treatment temperature: (a)Room temperature, (b) $100^{\circ} \mathrm{C}$, (c) $200^{\circ} \mathrm{C}$, (d) $300^{\circ} \mathrm{C}$, and (e) $350^{\circ} \mathrm{C}$

$350^{\circ} \mathrm{C}$ 의 열처리 열처리온도에서는 각 결합본드의 상대조 성에 큰 변화를 보여 주고 있는데, 이 경우는 높은 열 처리 온도로 인한 폴리이미드의 본격적인 퇴화에 기인하 는 것으로 판단된다.

Fig. 6은 열처리온도에 따른 peel strength 값의 변화 를 보여주고 있다. 열처리온도가 $200^{\circ} \mathrm{C}$ 까지는 온도에 따 른 접착강도는 매우 미미하게 감소하나 $300^{\circ} \mathrm{C}$ 부터는 급

Table 3. The elemental ratios on the peeled polyimide as a function of heat treatment temperature, obtained from the wide scan XPS spectra.

\begin{tabular}{ccccccc}
\hline \hline \multirow{2}{*}{ Sample } & & \multicolumn{5}{c}{ Elemental ratio (at.\%) } \\
\cline { 3 - 7 } & & O1s & N1s & C1s & Ni2p & Cu2p \\
\hline & Room & $16.26 \%$ & $3.58 \%$ & $80.16 \%$ & \\
Heat & Temp. & $16.75 \%$ & $3.08 \%$ & $80.17 \%$ & & \\
Treatment & $100^{\circ} \mathrm{C}$ & $16.86 \%$ & $3.03 \%$ & $80.11 \%$ & & $1.10 \%$ \\
& $200^{\circ} \mathrm{C}$ & $12.50 \%$ & $1.23 \%$ & $85.16 \%$ & & $0.74 \%$ \\
\hline
\end{tabular}


Table 4. The binding component ratios on the peeled polyimide surface as a function of heat treatment temperature, obtained fron the C1s XPS spectra.

\begin{tabular}{cccccc}
\hline \hline \multirow{2}{*}{ Sample } & & \multicolumn{4}{c}{ Binding component ratio (\%) } \\
\cline { 3 - 6 } & & $\begin{array}{c}\mathrm{C}=\mathrm{O} \\
(288.3 \mathrm{eV})\end{array}$ & $\begin{array}{c}\mathrm{C}-\mathrm{O} \\
(286.4 \mathrm{eV})\end{array}$ & $\begin{array}{c}\mathrm{C}-\mathrm{O}-\mathrm{C} \\
(285.6 \mathrm{eV})\end{array}$ & $\begin{array}{c}\mathrm{C}-\mathrm{C} \\
(284.6 \mathrm{eV})\end{array}$ \\
\hline & Room Temp. & $8.56 \%$ & $26.03 \%$ & $32.42 \%$ & $32.99 \%$ \\
Heat & $100^{\circ} \mathrm{C}$ & $8.48 \%$ & $25.25 \%$ & $32.40 \%$ & $33.87 \%$ \\
Treatment & $200^{\circ} \mathrm{C}$ & $8.21 \%$ & $25.84 \%$ & $32.34 \%$ & $33.61 \%$ \\
& $300^{\circ} \mathrm{C}$ & $4.80 \%$ & $30.22 \%$ & $38.16 \%$ & $26.82 \%$ \\
& $350^{\circ} \mathrm{C}$ & $11.32 \%$ & $10.73 \%$ & $25.45 \%$ & $52.50 \%$ \\
\hline
\end{tabular}

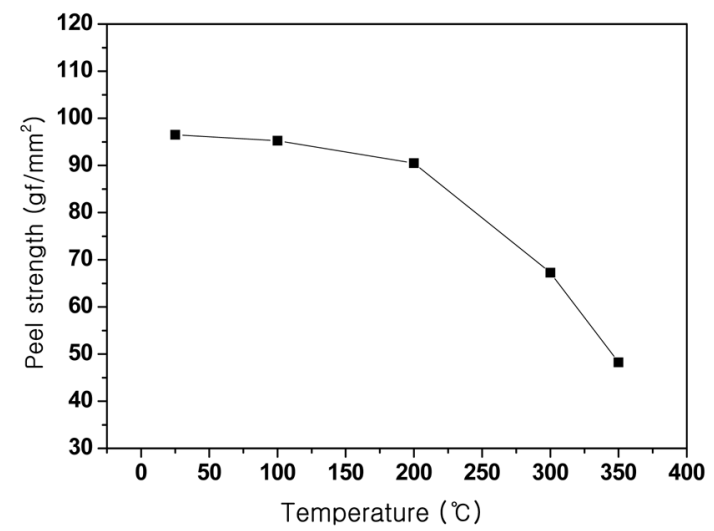

Fig. 6. The change of peel strength as function of heat treatment temperature.

격히 감소를 하고 있다. 이는 열처리온도 $300^{\circ} \mathrm{C}$ 에서는 Table 3에 나타난 바와 같이 $\mathrm{Cu}$ 가 $\mathrm{Ni}$ 박막층을 확산에 의해 통과하여 폴리이미드 계면과 접촉하게 되었고, 이 $\mathrm{Cu}$ 가 폴리이미드표면의 $\mathrm{C}=\mathrm{O}$ 본드와 결합하여 나타난 결 과이다. ${ }^{8,9)}$ 또한 $350^{\circ} \mathrm{C}$ 의 열처리온도에서는 $\mathrm{Cu} / \mathrm{Ni} /$ ployimide다층박막에 극심한 변형이 일어났고, peel stren$\mathrm{gth}$ 값은 더욱 감소되었으며, 시편간 접착력의 편차도 크 게 나타났다.

이상의 결과에서 $\mathrm{Cu} / \mathrm{Ni} / \mathrm{ployimide}$ 다층박막은 $200^{\circ} \mathrm{C}$ 의 비교적 높은 온도에서도 접착력의 큰 감소없이 사용이 가 능하나 $300^{\circ} \mathrm{C}$ 부터는 큰 접착력의 감소가 따르고, $350^{\circ} \mathrm{C}$ 이상의 온도부터는 심한 외관상의 변형도 발생되어 사용 이 불가능한 상태로 됨을 알 수 있다.

\section{4. 결 론}

$\mathrm{Cu} / \mathrm{Ni} /$ polyimide 다층박막system에서 접착력은 buffer layer $\mathrm{Ni}$ 박막 두께가 증가함에 따라 증가하나 $\mathrm{Ni}$ 박막의 두께가 $200 \mathrm{~A}$ 보다 두꺼워지면 그 변화는 미미하다. 이와 같은 $\mathrm{Ni}$ 박막 두께의 증가에 따른 접착력의 증가는 $\mathrm{Ni}$ 박 막과 폴리이미드계면에서의 $\mathrm{C}=\mathrm{O}$ 결합본드가 상호반응하
는데 기인된다. 또한, $\mathrm{Cu} / \mathrm{Ni} /$ ployimide다층박막은 $200^{\circ} \mathrm{C}$ 의 비교적 높은 온도에서도 접착력의 현저한 감소와 외 관상의 변형없이 사용이 가능하나 $300^{\circ} \mathrm{C}$ 부터는 큰 접착 력의 감소가 따르고, $350^{\circ} \mathrm{C}$ 이상의 온도부터는 심한 외관 상의 변형도 발생되어 사용이 불가능한 상태가 된다. $300^{\circ} \mathrm{C}$ 이상의 온도에서에서의 급격한 접착력의 감소는 이 러한 높은 온도에서 $\mathrm{Cu}$ 가 $\mathrm{Ni}$ buffer layer 층을 확산 통 과하여 계면에서 폴리이미드와 접촉하여 반응하는데 기 인된다.

\section{감사의 글}

이 논문은 2007년도 충북대학교 학술연구지원사업의 연 구비 지원에 의해 연구되었음(This work was supported by the research grant of the Chungbuk National University in 2007).

\section{참 고 문 헌}

1. R. R. Tummala and E. J. Rymaszewski (eds), Microelectronics Packaging Handbook, p.673, VNR, New York, (1989).

2. B. Chapman, Glow Discharge Processes, p.201, John Wiley \& Sons, New York, (1980).

3. L. P. Buchwalter, K. Holloway, J. Adhes. Sci. Technol., 12, 95 (1998).

4. M. J. Goldberg, J. G. Clabes and C. A. Kovac. Sci. Technol., A6, 991 (1988).

5. A. K. Oultache and R. E. Prud 'homme, Polym. Adv. Technol., 11, 316 (2000).

6. R. Haight, R. C. White, B. D. Silverman, and P. S. Ho. J. Vac. Sci. Technol. A6, 2188 (1988).

7. F. M. John, F. S. William, S. E. Peter, B. D. Kenneth, Hoodbook of X-ray Photoelectron Spectroscopy, p.41, Physical Electronics, Inc., USA, (1995).

8. M. H. Kim and K.W Lee, Met. Mater.-Int., 5(12), 425 (2006).

9. Y. H. Shin, J. S. Chu, S. W. Lee, C. H. Jung and M. H. Kim, Kor. J. Mater. Res., 1(15), 42 (2005). 